\title{
Comparison of a rapid cytomegalovirus pp65 antigenemia assay revealed by immunofluorescence to an in-house assay revealed by immunoperoxidase for diagnosis in solid organ transplant recipient patients
}

Authors

Emerson Carraro ${ }^{1,2}$

Jacyr Pasternak ${ }^{2}$

Ana Perosa ${ }^{2}$

Itacy Siqueira $^{2}$

Marines Dalla Vale

Martino $^{2}$

${ }^{1}$ Microbiology Section, Clinical Laboratory, Hospital Albert Einstein, São Paulo, SP, Brazil. ${ }^{2}$ Clinical Virology Laboratory, Infectious Diseases Department, UNIFESP, São Paulo, SP Brazil.
Submitted on: 03/04/2010 Approved on: 04/30/2010

\section{Correspondence to:} Dr. Emerson Carraro Laboratório de Virologia Clínica

Rua Pedro de Toledo, 781, $15^{\circ}$ andar,

Vila Clementino

São Paulo - SP - Brasil

CEP: 04039-032

Phone/Fax:

+55-11-50815394

E-mail: emersoncarraro@ bol.com.br

We declare no conflict of interest.

\begin{abstract}
Cytomegalovirus (CMV) antigenemia is still one of the two major assays available for diagnosis and monitoring of CMV infections. A commercial rapid test recently available in Brazil for quantification of human cytomegalovirus pp65 antigenemia revealed by immunofluorescence technique was compared with the original in-house method revealed by immunoperoxidase in patients receiving solid organ transplants. Of 80 blood samples tested for CMV antigenemia, 34 (42.5\%) were positive: commercial assay detected $33(97 \%)$ and in-house assay detected $20(58.8 \%)$ samples. The numbers of positive cells in the two assays were different, with a median of 4.5 and 12 positive cells obtained by in-house and commercial kit, respectively. Discrepancies between assays occurred in 15 specimens from patients with low-grade antigenemia (median 6 positive cells). The assay-time was reduced in approximately $50 \%$ compared to in-house methodology. In conclusion, besides comparable results obtained for both assays, the commercial antigenemia assay provides more rapid and sensitive results.
\end{abstract}

Keywords: cytomegalovirus, antigenemia assay, immmunoperoxidase, immunofluorescence.

[Braz J Infect Dis 2010;14(3):322-324] @Elsevier Editora Ltda.

\section{INTRODUCTION}

Cytomegalovirus (CMV) continues to be important pathogens in immunossupressed individuals, particularly transplant recipients and patients infected with human immunodeficiency virus. In addition to variable CMV clinical presentation, in transplant recipients, CMV disease can mimic the symptoms of allograft rejection, and differentiation is crucial because intensification of immunossupression would only aggravate CMV infection. ${ }^{1}$

Antiviral therapy can provide significant clinical benefit and be life-saving, provided that therapy is initiated promptly. It is therefore essential to have an assay that allows the rapid and reliable diagnosis of CMV disease and monitoring response to treatment. The CMV pp65 antigenemia detect and quantifies CMVinfected leukocytes by staining CMV pp65 antigens in peripheral blood. Many studies have shown that a positive result is strongly associated with active CMV infection and disease, can be used for monitoring antiviral therapy efficacy and in resistance emergency. ${ }^{2}$ However, the great limitation of this test is that it requires approximately 6 hours and is labor-intensive to perform. Several modifications in the technical procedure have been proposed since the initial use in the $80 \mathrm{~s},{ }^{3}$ but one-step, erythrocyte lysis without neutrophils concentration have demonstrated to save time and simplify the process. ${ }^{4}$ Recently available in Brazil, a commercial assay CMV Brite Turbo (IQ Products, Netherlands), with one-step erythrocyte lysis and revealed by immunofluorescence incorporated the main advantages of this procedure.

In this study, a rapid commercial Cytomegalovirus pp65 antigenemia assay, with revelation by immunofluorescence, was compared to an in-house assay, with revelation by immunoperoxidase, for detection and quantitation of CMV in clinical samples for transplant recipient patients.

\section{MATERIAL AND METHODS}

\section{Study samples}

Eighty fresh EDTA-anticoagulated blood samples from consecutive recipients of solid organ transplantation were submitted to the Albert 
Einstein Hospital Microbiology Laboratory for CMV pp65 antigenemia evaluation. From each patient, $5 \mathrm{~mL}$ of blood was used for in-house immunoperoxidase antigenemia assay and $1 \mathrm{~mL}$ was used for commercial immunofluorescence antigenemia assay. Each slide was evaluated by two well-trained readers independently, and only results with up to $10 \%$ difference in number of positive cells were accepted.

\section{In-house immunoperoxidase revealed CMV anti- genemia assay}

A total of $5 \mathrm{~mL}$ of EDTA-anticoagulated blood was mixed with $2 \mathrm{~mL}$ of $5 \%$ dextran solution (Amersham), and the mixture was incubated at $37^{\circ} \mathrm{C}$ for 15 min to allow sedimentation of erythrocytes in $45^{\circ}$ angle inclination tube. The leukocytes-rich supernatant was mixed with $10 \mathrm{~mL}$ of phosphated-buffered saline (PBS). After centrifugation at $200 \mathrm{~g}$ for $5 \mathrm{~min}$, the cell pellet was suspended in $8 \mathrm{~mL}$ of $\mathrm{NH} 4 \mathrm{Cl}$ solution $(\mathrm{NH} 4 \mathrm{Cl}[8.3 \mathrm{~g} / \mathrm{L}], \mathrm{KHCO} 3[1.0 \mathrm{~g} / \mathrm{L}]$, EDTA $[0.03 \mathrm{~g} / \mathrm{L}], \mathrm{pH} 7.4)$ on iced water for $10 \mathrm{~min}$ at $4^{\circ} \mathrm{C}$ for rupture of the remaining erythrocytes. The cells were then washed two times in PBS and centrifuged at $200 \mathrm{~g}$ for $5 \mathrm{~min}$. The final cell pellet was suspended in PBS and concentration was adjusted after leukocyte counts obtained in T890 cell analyzer (Coulter, USA). Cytospin slides were obtained by centrifugation of 3x105 leucocytes on glass slides at $500 \mathrm{rpm}$ for $5 \mathrm{~min}$ (Cytospin 3; Shandon, USA). After slide fixation with cold acetone for $5 \mathrm{~min}$, each slide was covered with $25 \mu \mathrm{L}$ of $1 / 10$ diluted CMV monoclonal mouse antibody clone C10/11 (Dako Cytomation, Denmark), and incubated for $45 \mathrm{~min}$ at $37^{\circ} \mathrm{C}$. After washing for 5 min with PBS, the slides were incubated with $25 \mu \mathrm{L}$ of 1/100 diluted Horserasch Peroxidase conjugated goat antimouse IgG antibody (Dako Cytomation, Denmark). After washing for 5 min with PBS, slides were incubated with 25 $\mu \mathrm{L}$ of AEC solution (3-amino-9-ethylcarbazole solution in $0.1 \mathrm{M}$ acetate buffer [ $\mathrm{pH} 4.9]$ ) for $10 \mathrm{~min}$ at room temperature in the dark for color development. This coloration was stopped with acetate solution for $5 \mathrm{~min}$, and negative leukocytes were stained with Mayer's Hematoxilin. The total numbers of positively stained leukocytes with bright red nuclei were counted by light microscopy and results ex-

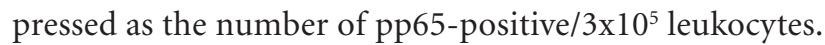

\section{Commercial immunofluorescence revealed CMV antigenemia}

A total of $1 \mathrm{~mL}$ of EDTA-anticoagulated blood was added to $14 \mathrm{~mL}$ of $0.8 \% \mathrm{NH} 4 \mathrm{Cl}$ solution in a plastic centrifuge tube and incubated at $4^{\circ} \mathrm{C}$ for $15 \mathrm{~min}$. Afterwards, the tube was centrifuged $200 \mathrm{~g}$ for $3 \mathrm{~min}$ and cell pellet washed twice with PBS under the same conditions of centrifugation. The final cell pellet was suspended in PBS and concentration was adjusted after leukocyte counts obtained in T890 cell analyzer (Coulter, USA). Cytospin slides were obtained by centrifu- gation of $4 \times 10^{5}$ leucocytes on glass slides at $500 \mathrm{rpm}$ for 5 min (Cytospin 3; Shandon, USA).The slides were air-dried, fixed with $5 \%$ formaldehyde, permeabilized with Nonidet $\mathrm{P}-40$, and incubated for $20 \mathrm{~min}$ at $37^{\circ} \mathrm{C}$ with $35 \mu \mathrm{L}$ of primary monoclonal antibody. After washing for 5 min with PBS, slides were incubated with $35 \mu \mathrm{L}$ of secondary antibody fluorescein isothiocianate-conjugated sheep anti-mouse immunoglobulin. At the end, the slides were washed with PBS and mounting glycerol and glass. The number of nuclear green fluorescence was scored under epifluorescence microscope at $40 \mathrm{X}$ magnification and results expressed as the number of pp65-positive/4x10 leukocytes.

\section{RESULTS}

The results are shown in Table 1. Of 80 samples tested, 34 (42.5\%) were positive by either or both CMV antigenemia tests. Of these, 19 samples were positive by in-house CMV antigenemia assay and commercial CMV antigenemia assay, with $20(55.8 \%)$ and 33 (97\%) samples detected in each assay, respectively. The numbers of positive cells in the two assays were different, with a median of 4.5 and 12 positive cells obtained by in-house and commercial kit, respectively.

Discrepancies between commercial assay and in-house developed assay results occurred in 15 specimens from patients with low-grade antigenemia. Only one positive sample in the in-house assay had two positive cells per $3 \times 10^{5}$ leukocytes, and the remaining discordant samples had median of 6.5 positive cells per $4 \times 10^{5}$ leukocytes. The difference between assays was obtained in different times to complete the assays results: approximately 6 hours for in-house assay revealed by immunoperoxidase and 3 hours for commercial assay revealed by immunofluorescence. Considering as true positive the result obtained by any of the tests, commercial CMV antigenemia and in-house assays had a sensitivity of $95 \%$ and $60 \%$, respectively, with $82.5 \%$ of accuracy and 0.62 Kappa index. None of the samples showed counts considerable different between the two independent readers in any assay.

Table 1. Comparison of immunofluorescence and immunoperoxidase stained CMV antigenemia among 80 solid organ transplanted patients

\begin{tabular}{cccc}
\hline IFI & IPO & number & $\begin{array}{c}\text { cell positive count } \\
\text { (median) }\end{array}$ \\
\hline+ & + & 19 & $12 / 4.5$ \\
+ & - & 14 & 6.5 \\
\hline- & + & 1 & 2 \\
\hline- & - & 46 & 0 \\
\hline
\end{tabular}

IFI, indirect immunofluorescence; IPO, immunoperoxidase. 


\section{DISCUSSION}

The quality of the stained slides was comparable between the two methods, with low nonspecific background staining and excellent leukocyte morphology. The technical handson time for the commercial CMV antigenemia kit was shorter and need less blood volume sample. Thus, the availability of a commercial assay that can be completed in 3 hours is of great benefit to the laboratory, as well as to patient care. Importantly, the 3 -h assay provided quantitative results equivalent to or slightly better than those of the standard test. ${ }^{5}$

Besides the reduced testing time, our results according to others authors indicate a good correlation between immunoperoxidase antigenemia and immunofluorescence antigenemia. ${ }^{5,6}$ Both assays use a mixture of C10-C11 monoclonal antibodies that react specifically with HCMV pp65 proteins giving reaction to different epitopes and improving the determination and quantitation of $\mathrm{CMV}$ antigenemia. ${ }^{7}$ Clinical significance of specimens found to be positive by only one test was not evaluated, but some discrepancies in the results produced by both tests was probably due to the more than $33 \%$ cells that were applied on slides for rapid testing, as recommended by the manufacturer. The justification for the increased number of cells is that standard dextran sedimentation for separation of leukocytes enriched for neutrophils, the cells predominantly express the CMV pp65 antigen in the peripheral blood. With direct erythrocyte lysis, there is presumably no such enrichment. Therefore, to obtain equivalent numbers of neutrophils, a greater number of cells must be examined. However, Ho et al. ${ }^{4}$ reported that differential counts of PBLs separated by dextran sedimentation versus direct erythrocyte lysis were, in fact, similar. We confirmed this finding.

Although antigenemia has been replaced by DNAemia for diagnosis and preemptive therapy of HCMV infection in some transplantation centers, pp65 antigenemia still remains the guiding assay for preemptive therapy in several other centers. ${ }^{8} \mathrm{~A}$ variety of sophisticated molecular tests are now available for CMV. In general, the reagents are more expensive, and special equipment and/or separate rooms are often required. Because of the time and expense involved in performing quantitative nucleic acid detection methods, single or even small numbers of samples are usually not tested. Rather, samples are batch tested once or several times per week. DNA based methods may be advantageous for reference laboratories with high test volumes and processing delays due to specimen transportation. ${ }^{9}$ However, in the hospital laboratory, CMV antigenemia has many advantages. None of the molecular tests can provide a quantitative result with a 2-h turnaround time. Pp65 CMV antigenemia commercial kits have limitations: influence of time delayed sample processing on cytomegalovirus antigenemia assay results in lowest positive cell counts. ${ }^{10-12}$ and impossibility of samples storage, ${ }^{13}$ besides the possibility that long-term storage can be achieved by keeping fixed slides at $-80^{\circ} \mathrm{C} .{ }^{9}$

In conclusion, the new commercial CMV antigenemia immunofluorescence revealed to have a good diagnostic value and faster assay for the detection and quantification of HCMV infection in solid organ transplanted patients.

\section{REFERENCES}

1. Grangeot-Keros L, Cointe D. Diagnosis and prognostic markers of HCMV infection. J Clin Virol 2001; 21:213-21.

2. Baldanti F, Revello MG, Percivalle E, Gerna G. Use of the human cytomegalovirus (HCMV) antigenemia assay for diagnosis and monitoring of HCMV infections and detection of antiviral drug resistance in the immunocompromised. J Clin Virol 1998; 11:51-60.

3. Van Der Bij W, Schirm J, Torensma R et al. Comparison between viremia and antigenemia for detection of cytomegalovirus in blood. J Clin Microbiol 1988; 26:2531-5.

4. Ho SK, Lo CY, Cheng IK, Chan TM. Rapid cytomegalovirus pp65 antigenemia assay by direct erythrocyte lysis and immunofluorescence staining. J Clin Microbiol 1998; 36:638-40.

5. Visser CE, Van Zeijl CJ, De Klerk EP et al. First experiences with an accelerated CMV antigenemia test: CMV Brite Turbo assay. J Clin Virol 2000; 17:65-8.

6. Gratacap-Cavallier B, Bonadona A, Berthier R et al. A simplified cytomegalovirus pp65 antigenemia assay procedure. J Clin Virol 2003; 28:317-22.

7. Gerna G, Revello MG, Percivalle E, Morini F. Comparison of different immunostaining techniques and monoclonal antibodies to the lower matrix phosphoprotein (pp65) for optimal quantitation of human cytomegalovirus antigenemia. J Clin Microbiol 1992; 30:1232-7.

8. Lilleri D, Gerna G, Furione M et al. Use of a DNAemia cutoff for monitoring human cytomegalovirus infection reduces the number of preemptively treated children and young adults receiving hematopoietic stem-cell transplantation compared with qualitative pp65 antigenemia. Blood 2007; 110:2757-60.

9. Landry ML, Ferguson D, Cohen S, Huber K, Wetherill P. Effect of delayed specimen processing on cytomegalovirus antigenemia test results. J Clin Microbiol 1995; 33:257-9.

10. Landry ML, Ferguson D, Stevens-Ayers T, De Jonge MW, Boeckh M. Evaluation of CMV Brite kit for detection of cytomegalovirus pp65 antigenemia in peripheral blood leukocytes by immunofluorescence. J Clin Microbiol 1996; 34:1337-9.

11. Niubò J, Pérez JL, Carvajal A, Ardanuy C, Martín R. Effect of delayed processing of blood samples on performance of cytomegalovirus antigenemia assay. J Clin Microbiol 1994; 32:1119-20.

12. Schäfer P, Tenschert W, Gutensohn K, Laufs R. Minimal effect of delayed sample processing on results of quantitative PCR for cytomegalovirus DNA in leukocytes compared to results of an antigenemia assay. J Clin Microbiol 1997; 35:741-4.

13. Boeckh M, Woogerd PM, Stevens-Ayers T, Ray CG, Bowden RA. Factors influencing detection of quantitative cytomegalovirus antigenemia. J Clin Microbiol 1994; 32:832-4. 